\title{
Norwegian Courts and Sámi Law
}

\author{
Øyvind Ravna \\ UiT The Arctic University of Norway
}

For decades, Norway has been viewed as a role model when it comes to safeguarding Sámi rights as an Indigenous people in the Nordic Countries. Among other reasons, this is because Norway is the only country with a Sámi population that has ratified ILO Convention No. 169. Also, Norway has adopted a particular land law where one of the purposes is to survey Sámi rights to land and water. It is also said that Norway has worked actively to ensure adoption of the 2007 UN Declaration on the Rights of Indigenous Peoples. Norway has gained international recognition for this work, among others from former UN Special Rapporteur on the Rights of Indigenous People James Anaya, who in his report on the situation of the Sámi people in Norway, Sweden and Finland, stated that Norway, since passing the Finnmark Act 2005, has set an important example for the other Nordic countries (para 44). ${ }^{1}$

In recent years, especially after controversial cases regarding the culling of reindeer herds and judgments passed after the survey of Sámi land rights in Finnmark, the image of Norway as an example to follow has faded and been replaced by criticism from the Sámi side. In a letter to the editor in the regional newspaper Nordlys 19 February 2021, President of the Sámi Parliament Aili Keskitalo, and Councilor of the Parliament Silje Muotka, stated that the courts have a lack of understanding of Sámi customs. The letter was a prelude to a case on legal security for the Sámi in the Sámi Parliament's plenary in March this year. In its presentation at the Sámi Parliament, the Council wrote that the topic has become important in recent years:

as Supreme Court decisions where Sámi interests have lost the case have led to strong reactions from large parts of Sámi society and from Sámi law expertise. This [...] may weaken the Sámi's confidence in the judicial system. ${ }^{2}$

During the plenary session, a large majority agreed with proposals to strengthen Sámi legal security and provide legal aid. It was also discussed whether the Sámi Parliament should contribute financially to court cases on principle legal disputes.

From the end of the 19th century and 100 years onwards, Sámi law, i.e., Sámi customs, and legal opinions, had no place in the Norwegian legal system. Similar

(C) 2021 Øyvind Ravna. This is an Open Access article distributed under the terms of the Creative Commons CC-BY 4.0 License. eISSN 2387-4562. https://arcticreview.no.

Citation: Øyvind Ravna. "Norwegian Courts and Sámi Law" Arctic Review on Law and Politics, Vol. 12, 2021, pp. 179-185. http://dx.doi.org/10.23865/arctic.v12.3417 
to the Sámi languages and other aspects of Sámi culture, legal culture was also suppressed by the official policy of Norwegianization. Significant are the words of District Court of Tana judge Erik Solem in his classic work Lappish Law Studies (Lappiske rettsstudier) from 1933. He wrote that:

certain rules have been formed on how the pastures should be utilized, and how the individual Lappish herder should behave when practicing reindeer husbandry. These rules are hardly so firm and definite that they can be maintained with the help of the courts. [...] the Laplanders themselves, however, most often respect the rules and never go to court to seek their enforcement. ${ }^{3}$

The Sámi could seldom expect good news when the third state power announced its decisions, of which the infamous Dergafjell and Marsfjell Supreme Court Cases from 1931 and 1955, respectively, are brutal examples. In these two cases, it was established that Sámi use could not lead to any rights which committed the landowner, or which the Norwegian state could not set aside by law. The situation improved somewhat in the 1970s and 80s, after the Norwegian Supreme Court in 1968 awarded the Swedish Sámi Village of Saarivuoma compensation for losses due to hydropower regulations and thus also recognized their ancient rights of use on the Norwegian side of the border (NRt. 1968 p. 429). The Alta case and the establishment of the Sámi Rights Committee in 1980 also put a greater focus on Sámi rights.

It was not until the beginning of the new millennium that the courts definitively ended the period of Norwegianization. In the Selbu Case, ${ }^{4}$ the Supreme Court in plenary emphasized that Sámi reindeer husbandry should be considered as reindeer husbandry - and not as peasant farming, which confirmed that the reindeer husbandry parties' rights were based on immemorial use. In addition to emphasizing Sámi customs and traditional use of land, the Court underlined the importance of the Sámi language and the fact that Sámi nature usage leaves few traces in the terrain.

Later the same year, the Supreme Court re-emphasized Sámi culture and legal opinions, which enabled a Sámi coastal population in Troms to establish property rights to community commons referred to as Svartskogen (NRt. 2001 p. 1229). The Parliamentary Standing Committee of Justice later stated, in the preparatory works of the Finnmark Act, that the two judgments "have given instructions on how traditional Sámi use is to be regarded as a basis for the acquisition of rights". Further, the cases were highlighted as important sources of law for the Finnmark Commission and the courts. ${ }^{5}$

In the Stjernøya Case (HR-2016-2030-A) fifteen years later, however, these instructions seem to have been forgotten. It was explained that the reindeer herding parties had demanded too much, and that if anyone should have property rights, it was the Sámi-descended villagers on the island. The result was that neither the reindeer herders nor the villagers acquired ownership rights; these rights were granted to the state's successor, the Finnmark Estate (Finnmarkseiendommen ( $\mathrm{FeFo})$ ). ${ }^{6}$ 
A unanimous Supreme Court also ruled that the State's disposition of land, as the presumed landowner from the 17th century onwards, had to be emphasized "in the usual way," despite the fact that the legislature, prior to adoption of the Finnmark Act, had acknowledged that "it [is] under current law difficult to conclude with certainty that the State's property rights can be fully maintained." ${ }^{\prime 7}$

A by-product of the case, unnecessary for the outcome of the ruling, was that the Supreme Court reduced the significance of the incorporation of the ILO Convention no. 169 into the Finnmark Act. Although the Finnmark Act directed (in section 3) that "the Act shall apply with the limitations that follow from ILO Convention No. 169 concerning Indigenous and Tribal Peoples in Independent Countries," and (in section 5) that the judicial survey should take place on the basis of prescription or immemorial usage, the Court found that the ILO Convention should not set guidelines for this judicial survey. The justice who pronounced the judgement here referred to the preparatory works of the Standing Committee of Justice, where it states:

The wording "with the restrictions" means that the ILO Convention takes precedence over the Finnmark Act if it turns out that provisions in the Act are in conflict with provisions in the ILO Convention. If, on the other hand, it is concluded, on the basis of the ILO Convention, that the Act lacks provisions of a certain content, this will be a task for the legislature. In other words, the court shall not use the ILO convention to expand the Finnmark Act. ${ }^{8}$

Apparently, this meant that incorporation of the ILO 169 was intended to be limited to the Finnmark Act's own provisions. Thus, the Convention, although precedent to the Finnmark Act, does not regulate the substantive rules on the basis of which the rights are to be clarified. Consequently, ILO 169 became almost irrelevant to the judicial survey in central areas of Sápmi.

Another judgement that aroused reactions in Sámi communities was the so-called Jovsset Ánte Sara Case (HR-2017-2428-A), where the Supreme Court ruled that a young reindeer owner had to reduce his herd from 116 to 75 animals. In her 2018 New Year's speech, the President of the Sámi Parliament stated that the judgement was unfair. Especially notable is her statement that "when the Norwegian state is built on the territory of two peoples, the rule of law [...] must be based on the legal understanding of two peoples". ${ }^{9}$

Just a few days after this speech was delivered, the Supreme Court was set plenary to decide on a local community's claim to govern use rights - use rights they indisputably held. The case was brought before the Supreme Court by the Finnmark Estate, which in the Uncultivated Land Tribunal of Finnmark, had argued that a local community in the Sámi municipality of Nesseby / Unjarga, should not be allowed to govern or manage the use rights that the Estate agreed the community had. After losing the case in the Tribunal, The Finnmark Estate petitioned the Supreme Court. The claim of the local community in the Nesseby Case (HR-2018-456-P) was 
rejected by a unanimous Supreme Court, which upheld that the State had acted as property owner in the area since 1780 . Thus, the right to restitution provided by ILO 169 was deemed irrelevant. The Chief Justice first voting judge emphasized the uselessness of the claim of governing rights by stating: "The local population has not made any demands for property rights. In my view, there is no basis for such a claim." ${ }^{10}$ Later it was shown that the historical fact upon which the Supreme Court based its decision, contained demonstrable errors. ${ }^{11}$

The outcome of the Nesseby case could be explained politically in that the reindeer herding Sámi and an adjoining community took the side of the Finnmark Estate, and that the area was also used by others. This was not the case in Gulgofjord, where descendants of coastal Sámi from a settlement that was evacuated in 1970, claimed property rights to an outlying area close to the previous settlement. By placing heavy emphasis on presumed state-ownership-dispositions that were probably nonexistent, the Uncultivated Land Tribunal swept away any doubt that the Finnmark Estate owned the disputed area (UTMA-2017-62459). The Sámi Parliament, in its 2018 report to the UN Committee on Racial Discrimination (CERD), later stated that the Court "has placed decisive emphasis on earlier unlawful state dispositions as setting legal precedents at the expense of already accrued Sámi rights". ${ }^{12}$

With the so-called green shift, a huge number of wind turbines have been constructed in reindeer herding areas, pushing the Sámi from bulwark to bulwark also in the courts - where pre-accession for irreversible interventions has been given before their legality has been tried. The case of the Øyfjellet Wind Power Plant near Mosjøen in Nordland county is not only a grotesque example of this practice, but has also been a financial disaster for the reindeer herders who brought the case to court. Jillen-Njaarke Reindeer Husbandry District had demanded a halt in construction of the enormous Wind Power Plant, pending a ruling on the legality of the construction. The power plant, which according to the developers' website will be Norway's largest, will close the reindeer husbandry district's migration route and thus violate Reindeer Husbandry Act section 22, which states that "The reindeer husbandry's migration routes must not be closed". ${ }^{13}$ Establishment of the plant would also challenge Norway's obligations under the UN Convention on Civil and Political Rights (ICCPR), Article 27. A request for a halt (temporary injunction) in construction pending its legality was therefore put forward by the reindeer husbandry district. However, the Oslo City Court, which dealt with the case in the first instance, did not find that there was reason to wait for clarification of the legality.

The price of opposing this intervention was enormous; after four days in court, the reindeer herders had to pay NOK 1.77 million (approximately 170.000 Euros) to the wind power investors (or speculators) Øyfjellet Wind AS and Eolus Vind Norge Holding AS. In the appeal case decided in February this year, the Borgarting Court of Appeal (LB-2020-172267) did not find these costs problematic. Nor was the 
closure of the migration route seen as unacceptable, as the reindeer could use other winter pastures or be moved by truck. The appeal was rejected.

In April 2021, another case attracted the attention and ire of Sámi communities. On 10 February the same year, Hålogaland Court of Appeal sentenced a Sámi from Kautokeino to 14 days conditional imprisonment and loss of the right to hunt for one year for having conducted spring hunting on ducks before hunting season opened in the area. The verdict was appealed to the Supreme Court. Although the Appeals Committee of the Supreme Court found that the hunt had been in line with Sámi customs, cf. ILO 169 Article 8, the Appeals Committee - like the Court of Appeal - found that consideration of restrictions on hunting time weighed heavier than Sámi custom. The Appeals Committee subsequently refused to submit the appeal to the Supreme Court. This provoked a reaction from the President of the Sámi Parliament, who in a statement to the newspaper said that it was regrettable that the case was rejected. ${ }^{14}$ The mayor of Kautokeino, Hans Isak Olsen, was even clearer and stated to the same newspaper that ILO Convention No. 169 should have preceded the Norwegian law in this case. He further said that this case shows that the Sámi culture has zero value in the Norwegian legal system. ${ }^{15}$

In May 2021, the Supreme Court heard the question of the grazing rights of the Swedish Sámi Village of Saarivuoma. Saarivuoma Sámi village from the Kiruna area in Sweden is identical to the one that won a pioneering case against the Norwegian State in 1968. However, four years later the Swedish Sámi had to give up their traditional areas in Norway as a result of the Swedish-Norwegian reindeer grazing convention of 1972. After the two countries failed to renegotiate the grazing convention in 2005, Sweden declared that the more than 250-yearold Lapp Codicil - an annex to the border treaty between Norway and Sweden of 1751 - went into force again. Norway, for its part, unilaterally continued the convention from 1972. This resulted in a disorderly situation - and lawsuits - in which Saarivuoma and the neighboring district of Talma without exception lost in the lower courts. There was therefore great expectations about the outcome of the ruling in the Supreme Court - not least because Norwegian Sámi currently use the disputed area where Saarivuoma previously had exclusive rights - and because of the considerable time that passed between the conclusion of the appeal negotiations and the ruling.

On 30 June 2021 the Supreme Court pronounced its judgement, where the five judges were divided into three factions. Two of the judges found that Saarivuoma had grazing rights in the disputed areas due to immemorial usage and that they were entitled to compensation for unlawful interference in grazing rights as a result of state regulations. Two other judges agreed on the question of grazing rights, but not compensation. The fifth judge - in agreement with the lower courts - found that the Norwegian unilaterally-adopted reindeer grazing law of 2005 provided a legal basis for the current regulation of grazing areas, and that the Swedish Sámi thus neither 
had grazing rights nor the right to compensation. The result was that a majority of four judges decided that grazing rights existed, which was certainly the most important thing for Saarivuoma Sámi village, and which is seen as legitimate by the majority of the Sámi - both in Norway and Sweden.

However, criticism has been leveled at the inconsistency of not granting compensation for a grazing regulation that was declared illegal, including in an editorial in the Sami newspaper Ságat stated:

It is completely unheard of for the Norwegian state to be exempt from paying compensation for losses caused by unlawful legislation to private rights holders. The effect of this is that the country's highest court has given acceptance that the state can, with impunity, adopt illegalities that prohibit and criminalize legal activity. ${ }^{16}$

Two weeks later, on 17 July, another verdict was handed down in favor of reindeer herding Sámi. The verdict, which was pronounced by the Hålogaland Court of Appeal, had its background in a lawsuit from landowners in Vesterålen in Nordland County who argued that reindeer husbandry prevented the use of their property including the establishment of a ski trail. Somewhat surprisingly, in December 2020, the Vesterålen District Court ruled that the Kanstadfjord Vestre Hinnøy Reindeer Husbandry District was not entitled to use pastures in the disputed area, which constituted outlying grazing areas within the Sámi Reindeer Husbandry area ${ }^{17}$ close to the town of Sortland.

After a historical review of the use of the disputed area, the Court of Appeal concluded that the right to reindeer husbandry in the area undeniably existed. The Court of Appeal also stated that it is not unreasonable that the right applies to areas close to a town - and that conflicts of interest are not an argument that the reindeer herders' rights no longer apply or can be restricted. Furthermore, the Court of Appeal held that this was not a case for the courts.

These last two judgments paint a somewhat more nuanced picture of a legal situation, which over the last five years has largely been in Sámi disfavor, and which has been characterized as unfair. However, the great litmus test on law and justice in Sámi cases started in the Norwegian Supreme Court yesterday on 25 August, in a case where the Grand Chamber of the Supreme Court will assess the legality of the construction of the Fosen Wind Power Plant, a power plant that vies with the aforementioned Øyfjellet Wind Farm to be Norway's largest intervention in reindeer husbandry areas. In the case, the Supreme Court will assess the compensation assessment, which the wind power investors argue is set too high. Far more interesting is that the Supreme Court also will decide whether construction of the power plant violates Norway's international law obligations towards the Sámi, including the right to enjoy their own culture according to ICCPR article 27 . That the case is being heard after construction and irreversible damage has already taken place, and that the Norwegian State has intervened in the case on wind power party's side - not to ensure that international law is complied with, but so that a possible violation 
of international law is not declared unlawful - means that it will be followed extra closely from the Sámi side.

Like the Sámi Parliament, the Norwegian Court Commission of 2017 has focused on the Sámi situation in the courts and called for insight and knowledge from judges and the specific courts when it comes to Sámi legal issues. ${ }^{18}$ It remains to be seen how the courts - and especially our highest court - will respond to the orders from the Sámi Parliament and the Court Commission. Much of the answer to this will be revealed in the abovementioned Grand Chamber case which has just commenced.

The article is based on a keynote speech delivered at the National XIX Legal Research Conference 2021: Sustainable and Responsible Law for Society, 26 August 2021, University of Lapland, Rovaniemi, Finland (a Norwegian translation of the speech was published in Ságat, 27 August 2021).

\section{NOTES}

1. The situation of the Sami people in the Sápmi region of Norway, Sweden and Finland, 2011, (A/HRC/18/35/Add.2), para 44.

2. Sametingets rolle i rettsprosesser, rettshjelp og samisk rettsikkerhet (The Sami Parliament's role in legal proceedings, legal aid and Sami legal security), The Sami Parliament's plenary session, archive no. 20/4589, 9-12 March 2021 (my translation here and elsewhere).

3. Erik Solem, Lappiske rettsstudier, Oslo 1933, p. 188.

4. Norsk Retstidende (NRt.) 2001 p. 769.

5. Innst.O. nr. 80 (2004-2005) p. 36.

6. The Finnmark Estate is the body that has been appointed by the 2005 Finnmark Act to own and govern the Finnmark residents' joint ownership of former state land. In practice, the body has put greater emphasis on continuing the former state-ownership-governance than representing local rights holders.

7. Ot.prp. no. 53 (2002-2003) p. 43.

8. HR-2016-2030-A para. 75 (with reference to Innst.O.nr.80 (2004-2005) p. 33).

9. Ságat, 1 January 2018 (https://www.sagat.no/nyheter/les-hele-nyttarstalen/19.10806).

10. HR-2018-456-P para. 112.

11. Øyvind Ravna, "Den tidligere umatrikulerte grunnen i Finnmark: Jordfellesskap fremfor statlig eiendom?”, Tidsskrift for rettsvitenskap, 02-03/2020 (vol. 132), pp. 219-263.

12. The Sámi Parliament's 2018 Report to CERD For the period from 2014 up to and including 2018 (2018) p. 16.

13. Lov 15. juni 2007 nr. 40 om reindrift (Act 15 June 2007 no. 40 on Reindeer husbandry).

14. Ságat, 27 April 2021.

15. Ságat, 26 April 2021.

16. Ságat, 12 July 2021.

17. Within the Sámi Reindeer Herding area, legal status is that the Sámi have the right to practice reindeer husbandry on the basis of immemorial usage, cf. the Reindeer Husbandry Act section 4 first paragraph. If the landowner or others, however, can prove that the area has not been used for reindeer husbandry from olden days, this right may be non-existent.

18. NOU 2019: 17 Domstolstruktur, Delutredning fra Domstolkommisjonen, 1 October 2019 and NOU 2020: 11 Den tredje statsmakt - Domstolene i endring, Utredning fra Domstolkommisjonen, 30 September 2020. 